Univerzitet u Beogradu
Poljoprivredni fakultet
Institut za poljoprivrednu tehniku
Naučni časopis
POLJOPRIVREDNA TEHNIKA
Godina XLVI
Broj 4., 2021.
Faculty of Agriculture
Strane: $97-120$

\title{
CROP - MACHINERY MANAGEMENT SYSTEM FOR FIELD OPERATIONS AND ADOPTED PLANNING TECHNIQUES FOR PLANTATION SUGAR CANE PRODUCTION
}

\author{
Alex Folami Adisa*1, Nseobong Obioha Eberendu ${ }^{1}$ \\ 1.Aricultural and Bio-resources Engineering Department, \\ Federal University of Agriculture, Abeokuta, Nigeria
}

\begin{abstract}
Major objectives of farm mechanization are to maximize production at minimum risks and optimum cost of equipment usage by good management planning and operation of machines to carry out sequence crop production operations for the whole farming system. Hence this study was needed at Sunti Golden Sugar Company, Nigeria to determine cost of equipment use and select appropriate tractor power and machinery for the crop cultivation, crop establishment, weed control, cane harvesting and transporting to the store for post- harvest processing for future target of 4,770 ha of sugar cane farm. Based on agricultural farm size, field operational planning factors like soil. weather/environmental conditions, each implement matched with appropriate tractor size was calculated. Costs of equipment use, ownership and operational costs for implements and tractors were also calculated. A well-drawn cropping field operations calendar was very important for crop and operational sequencing was recommended and was put inplace since the operations overlaps with multi-periods. As part of the recommendation, during the planned equipment downtime, major repairs and maintenance were to be carried out before critical field operation's period to improve pre-field and in-field efficiency for effective equipment and field operational planning and management. Determined are the values of each implement field capacity within allotted time available, actual number of implement/tractor power required, fuel and oil consumption per unit time for the sugar cane cultivation, harvesting and transporting operations at the sugar cane farm. Also appropriate earthmoving and earthwork equipment for road, irrigation and drainage structural works were also selected.
\end{abstract}

Key words: Cropping calendar, machinery, management, operational, sequencing

*Corresponding Author. E-mail: alexadisa(a)yahoo.co.uk 


\section{INTRODUCTION}

Agricultural mechanization is all forms of mechanical assistance at all levels of sophistication which usually involves injection of capital and is labour augmenting.

Agricultural mechanization must be seen in the context of a broad agricultural development strategy whose objectives are likely to be agricultural productivity in order to increase the sector's contribution to economic growth and security; increase rural welfare, income, employment, living standards and poverty alleviating; achieving social modernization, attitudes and behavior. Mechanization level decisions need to consider number one, farm power requirements to increase agricultural productivity and secondly appropriate technology that is cost effective, choice consistent with resources availability, social and economic objectives, [1]. Agricultural operation maximum profitability is possible with good knowledge of agricultural machinery management to eliminate costly mistakes for optimum system cost, [2].

Farm mechanization major objectives are to maximize production at minimum risks by good management planning and operation of machines to carryout sequence crop production operations for the whole farming system [3]. This requires study of relationship and identification of crop to be cultivated, operations, machines and weather which can control machine capacity in-term of width, speed, and field efficiency also selecting appropriate implement within time availability, operation and crop [3]. The goal of good crop-machinery management is to have a system that is flexible enough to adapt broad range of weather, soil and crop conditions at minimal long-run costs and production risks, [4].

Factors to be considered are machine performance to carryout operations, machinery running/operational costs, machinery size selection, operational timeliness like tillage, planting and harvesting dates effect on production, field capacity of machine, matching tractor power and implement size, operational scheduling for optimum output, [4].

\section{MATERIAL AND METHODS}

\section{Characteristics of the study areas}

Sunti Golden Sugar Estate is a subsidiary of Flour Mills of Nigeria Plc which is a 15,000 ha of acquired fadama land located at northern side of River Niger, southern part of Jebba Dam Hydroelectric Power Station, Niger State, Nigeria. Figure 1 is the layout of the estate features. 


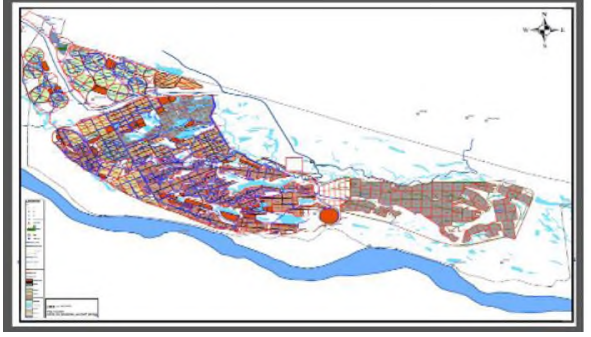

Fig.1. Features layout of the estate, Source: Sunti Golden Sugar Etsate map, 2018

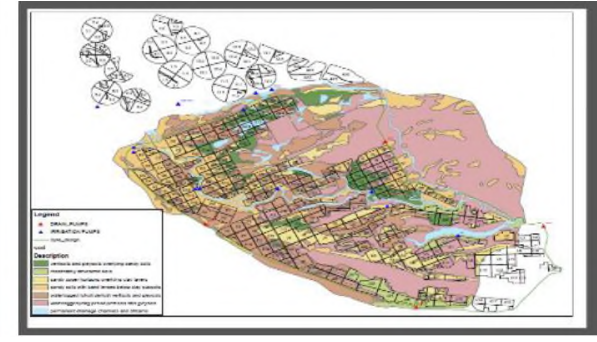

Fig.2. Soil map of the estate, Source: Sunti Golden Sugar Estate map, 2018.

Presently only about 4,770 ha of the land acquired was found suiTab. for sugar cane cultivation, 930 ha is the total land surface area covered by small lakes and channels of water. The remaining 9,300 ha of land was found not sui Tab. for sugar cane cultivation because of the soil high water Tab. level. The top soil depth ranged between $30 \mathrm{~cm}$ to 40 $\mathrm{cm}$ while available sugar cane varieties root depth is from $50 \mathrm{~cm}$ to $150 \mathrm{~cm}$. Figure 2 is the soil map of the estate.

\section{Agricultural Field Operations Planning.}

The followings are the relevant information needed but most of it was not available from captured data for the current and previous cropping seasons:

- Field operational management hierarchy

- Take off time of cropping seasons and previous was required.

- Intended ratooning field to be cultivated, that is, size/season (ha/year).

- What was accomplished for ratooning (ha).

- Intended new field to be cultivated size/season (ha).

-What was accomplished for newly developed field (ha).

- Targeted plowing/harrowing operation (ha).

- Targeted row marking operation (ha).

- Targeted cane planting operation (ha).

- Targeted herbicide application operation (ha)

- Targeted fertilizer application operation (ha).

- Targeted soil moulding/forming of ratoon fields.

How much of these targets were achieved at specified time for the current and previous seasons?

What are the observed factors that resulted for not meeting the targeted operation for the current and previous seasons, for example:

- Field too wet and delayed machine operation (h) due to rainfall.

- Idle time travelling to field location (h).

- Machine clogged and sank in mud time which delayed operation (h).

- Average time spent in filling fertilizer box for application (h).

- Average time spent in filling sprayer with water and mixing chemical (h).

- Method and planting operation (h).

- Method and harvesting operation (h).

- Cane harvesting (h)

- Cane loading (h).

- Cane transportation to the factory $(h)$. 


\section{Tillage implements rating size and width}

- Rome harrow of disc size $711 \mathrm{~mm}$ (28') and $5.6 \mathrm{~m}$ to $5 \mathrm{~m}$ width.

- Rome plow of disc size $914 \mathrm{~mm}$ (36") and $2.55 \mathrm{~m}$ width for old ratoon and $1,067 \mathrm{~mm}$ (42") and $2.55 \mathrm{~m}$ width for newly developed land.

- Three row ridger of disc size $711 \mathrm{~mm}$ (28") and $5.5 \mathrm{~m}$ width.

- Single row ridger of disc size $711 \mathrm{~mm}\left(28^{\prime \prime}\right)$ and $1.2 \mathrm{~m}$ width.

Figures 3 and 4 are some of the tillage implements, while Figure 5 is a field prepared and was being planted with sugar cane at the study site during 2018 cropping season.

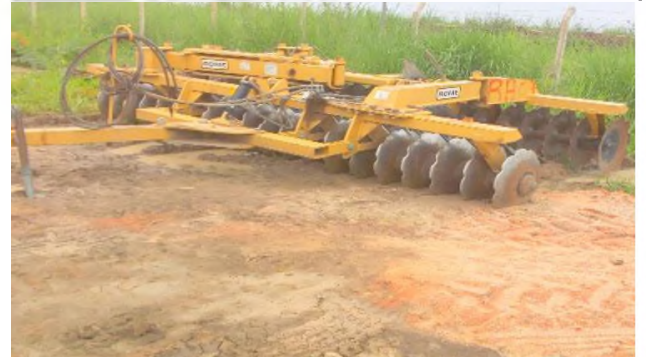

Fig. 3. A rome plow for deep plowing operation

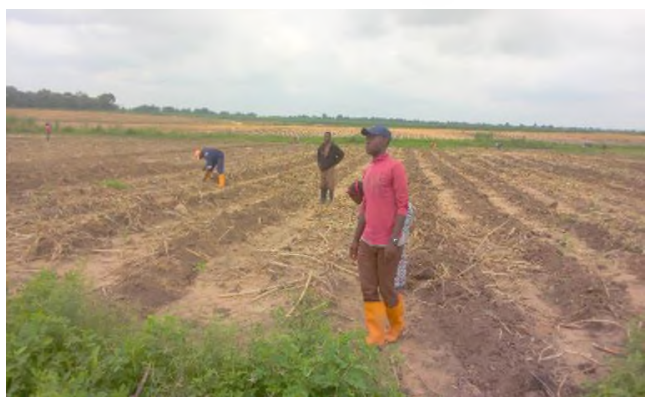

Fig. 5. Field being manually planted by both female and male laborers

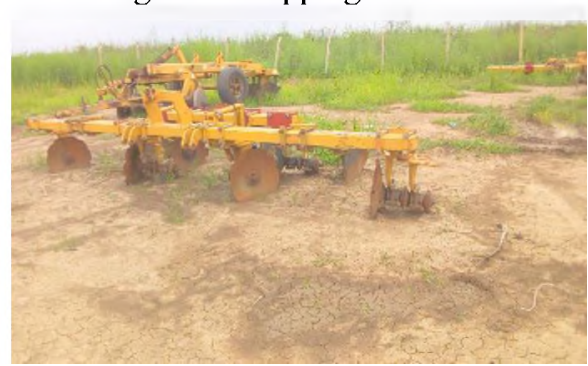

Fig. 4. A soil moulding/forming implement

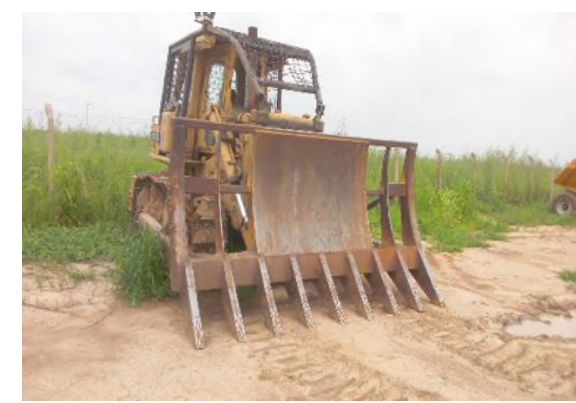

Fig. 6. Crawler tractor mounted with raking Blade for land developmet windrowing, raking and root de-stumping

\section{Land Development, Earth Works, Civil, Roads Equipment}

Figure 6 is one of the crawler tractor mounted with equipment used for land clearing, raking and root de-stumper which was as well mounted with A Rome blade for tree felling and earth moving/work operations.

\section{Irrigation and drainage system assessment}

Factors for major source of water for the irrigation system in the estates and also major drainage channel to discharge excess water from fields for both irrigation and drainage assessment: 
- Water available/storage for irrigation system were from abundance of scores of lakes/channels.

- Irrigation types in relation to soil classification.

- Sprinkler system (ha)/depth of application/irrigation scheduling.

- Rain gun system (ha)/depth of /irrigation scheduling.

- Availability of enough primary, secondary and tertiary lines, risers and sprinkler heads.

- Availability of labour to change lines, maintain/repair and operate pumps.

- Pivot system (ha)/depth of application/irrigation scheduling.

- Surface/flood system (ha)/depth of application/irrigation scheduling.

- Pumping capacity for overhead irrigation system, $\mathrm{m}^{3} / \mathrm{h}$.

- Pumping capacity for surface/flood irrigation system, $\mathrm{m}^{3} / \mathrm{h}$.

- Pump station maintenance and supply of fuel and servicing parts.

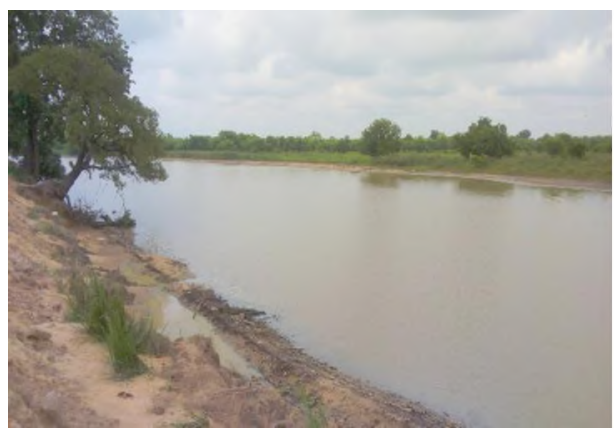

Fig. 7. One of the lake that is serving as sources of irrigation water/drainage outlet

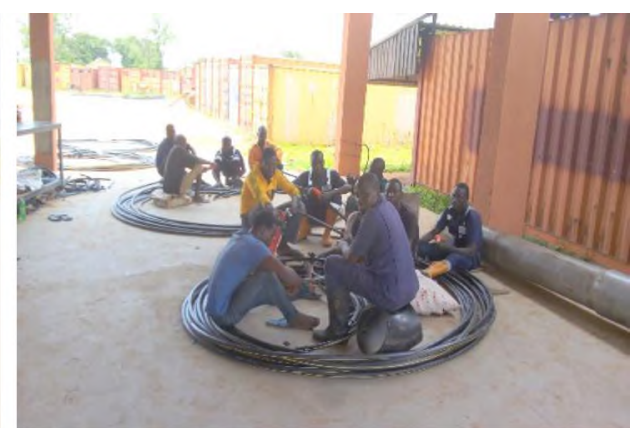

Fig. 8. Sprinkler irrigation lines being assembled in irrigation workshop

The irrigation application depth requirement for the soil type is $180 \mathrm{~mm}$ to $200 \mathrm{~mm}$ per irrigation scheduling of 6 hours/day of 6 day circle. Figure 7 is a lake that is serving as one of sources of irrigation water/drainage outlet, Figure 8 is sprinkler irrigation lines being assembled in irrigation workshop, preparing for season's irrigation operation, Figure 9 is a pivot irrigation system, Figure 10 is an earth canal for surface irrigation, Figure 11 is a pump station for surface irrigation, Figure 12 is a completed drainage pump station lifting water above the dyke out of the field and Figure 13 is a fuel bowser for supplying fuel from one pump station to another.

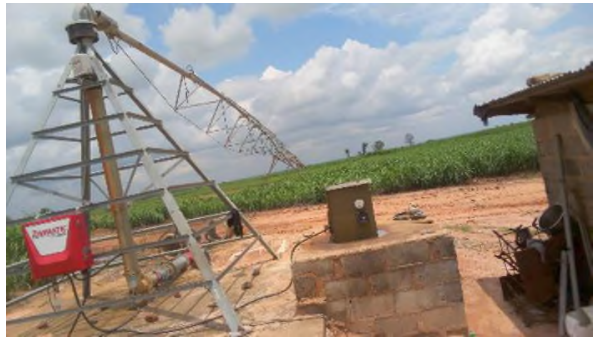

Fig. 9. A pivot irrigation system

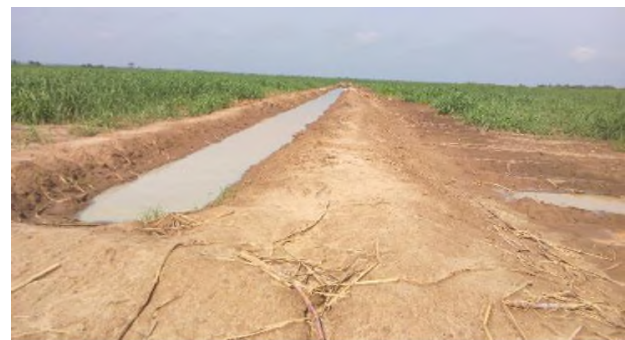

Fig. 10. An earth canal for surface irrigation 


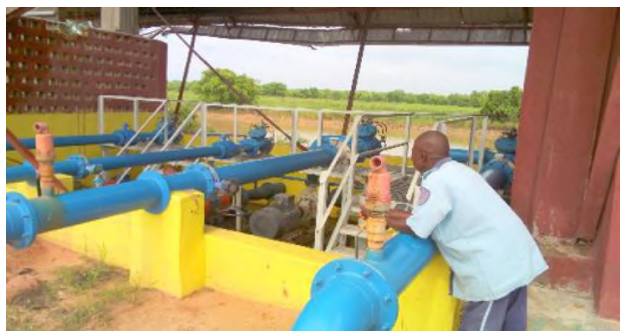

Fig. 11. Pump station for surface irrigation station

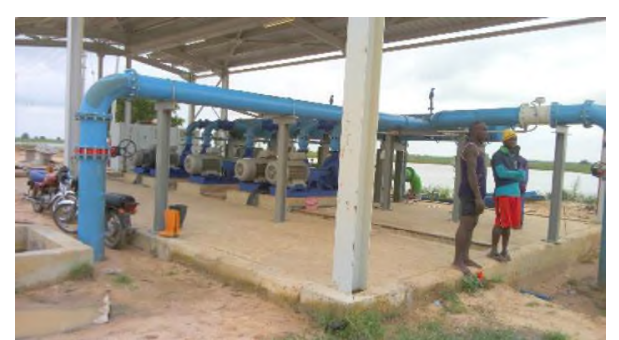

Fig. 12. A completed drainage pump lifting water above the dyke out of the field

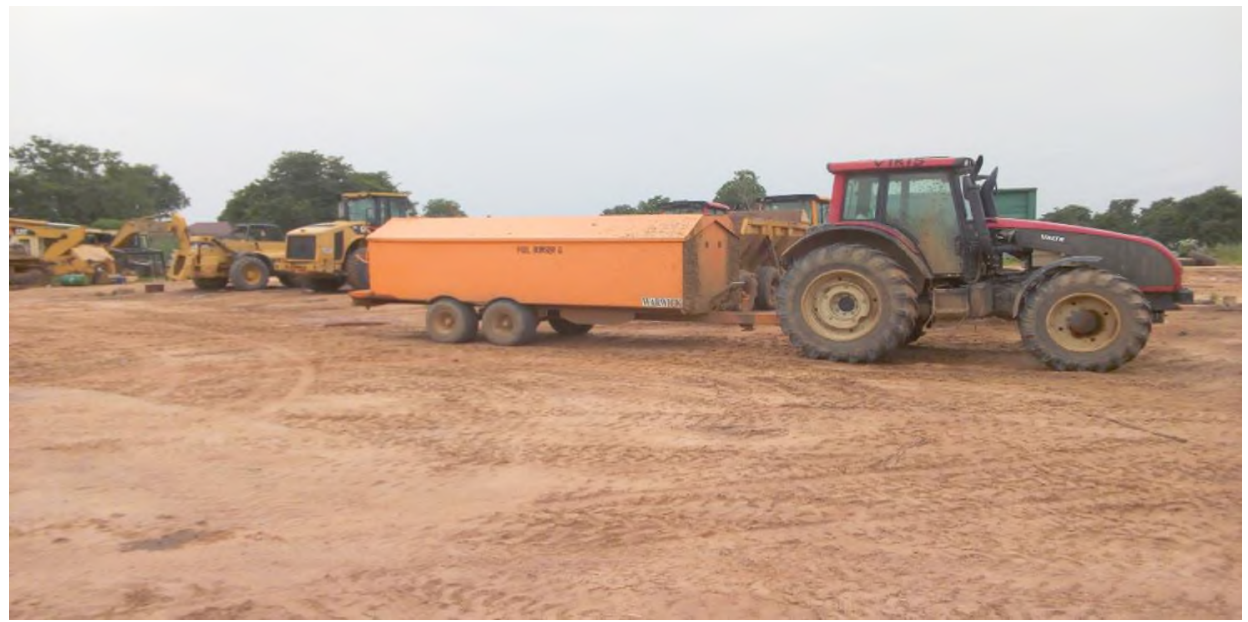

Fig.13. A fuel bowser for supplying fuel from one pump station to another

There are several pump stations for irrigation and drainage operations, some with two pumps of $2,200 \mathrm{~m}^{3} / \mathrm{s}$ and $220 \mathrm{~kW}$ from River Niger, a $410 \mathrm{~kW}$ motor pump at Batagi, a single pump to assist some field which is of $87 \mathrm{~m}^{3} / \mathrm{h}$ capacity, five pumps in a station of $500 \mathrm{~m}^{3} / \mathrm{h}$. Sabotunga station with four pumps, Sunti station with four pumps, drainage pump station (DPS) 3 station with three giant pumps and DPS 6 with six giant pumps under construction because of serious drainage problem encounter during the raining season.

\section{Machinery Management Procedure}

This section dealt with farm equipment requirement determination for implements and source of power, tractor. This was determined by using operations required, area to be covered per unit time and implement type specified for the crop production procedure which consist machinery selection, power requirement and machinery costs [3].

The available period for land preparation at Sunti Golden Sugar was from October to April of the following year with December as break (6 months). The daily field day work starts from 8:00 am to 3:00 pm with one hour break (6 hours) from Monday to Saturday ( 6 days) and operates four weeks in a month at peak period of operations. 
The target area to be covered is 4,770 ha out of 14,070 ha for future expansion on the total land acquired for the sugar cane plantation. The equipment selection was based on yearly ratoon/newly developed replanting of 1,000 ha for ripping, deep plow and row marking fields.

\section{Field machine capacity requirement calculations}

Machinery selection procedure was to determine the size and the number of implements and power units required to complete field operations within time available by calculating effective field capacity $(\mathrm{ha} / \mathrm{h})$. Required parameters include speed of field operation, field efficiency, available working days and available working hours per day [5].

\section{I.Field capacity}

Effective field capacity $\left(\mathrm{C}_{\mathrm{a}}\right)$ on area basis is expressed in ha/h and was calculated using total farm area and total time available to carry out each field operation using eq. (1).

$$
C_{a}=\frac{v w f}{10} \frac{h a}{h}
$$

Where:

$v=$ travel speed, $\mathrm{km} / \mathrm{h}, w=$ machine working width, $\mathrm{m}, f=$ field efficiency,

Or

Effective field capacity was calculated [3] as follows using eq. (2)

$$
C_{a}=\frac{A}{D x h}
$$

Where:

$A=$ area under operation, ha, $D=$ available working days,

$h=$ available working hours per day, $h$

From eq. (2) when area $A$ is 1,000 ha for ripping of replanted/newly developed fields:

$C_{a}=\frac{1,000}{6 \times 6 \times 3 \times 4}=2.31 \mathrm{ha} / \mathrm{h}$

\section{II.Required width}

For heavy- duty plowing/tandem disk harrow, if field efficiency,

$f$ is $75 \%$ and operating speed, $v$ is $7 \mathrm{~km} / \mathrm{h}$ from eq. (1).

With $C_{a}=\frac{v w f}{10}=2.31 \mathrm{ha} / \mathrm{h}$

Then, $w=\frac{2.31 \times 10}{7 \times 0.75}=4.40 \mathrm{~m}$

III.Number of machine(s) required

Number of machine(s) required $M$ was calculated using eq. (3).

$M=\frac{W}{M A W W}$

Where: $M=$ number of machine required,

$M A W W=$ maximum available working width, $\mathrm{m}$

Effective field capacity $C_{m}$ on a material basis is expressed in $\mathrm{Mg} / \mathrm{h}$ using eq. (4)

$$
C_{m}=\frac{v w Y f}{10}
$$

Where: 
$C_{a}=$ field capacity, area basis, ha/h $\left(C_{a t}\right.$ when $\left.{ }_{\mathrm{f}}=1.0\right)$,

$\mathrm{C}_{\mathrm{m}}=$ field capacity, material basis, $\mathrm{Mg} / \mathrm{h}\left(\mathrm{C}_{\mathrm{mt}}\right.$ when $\left.f=1.0\right)$,

$Y=$ crop yield, $\mathrm{Mg} / \mathrm{ha}$.

\section{IV . Machinery power requirement}

Machinery field operation draft and power requirements are important when selecting tractors and implements because tractors must be of adequate size to meet implement draft requirements. Tractors' engine or self-propelled machines must be large enough to supply the power requirements of the field operations on which this was based, [5].

(a). Draft requirement calculation using eq. (5).

$$
D=F_{i}\left(A+B v+C v^{2}\right) w d
$$

Where:

$D=$ implement draft, $F_{i}=$ dimensionless texture adjustment factor,

$i=1$ for fine, 2 for medium, or 3 for coarse textured soils,

$A, B$, and $C=$ implement specific constants,

$d=$ tillage depth, cm (use 1.0 for minor tillage tools and seeders),

$v$ - travel speed, $\mathrm{km} / \mathrm{h}$.

(b). Drawbar power calculation using eq. (6).

$P_{d b}=\frac{D v}{3.6}$

Where:

$P_{d b}=$ drawbar power, $\mathrm{kw}$

(c). Power take off (PTO) power determination:

This can be estimated using Fig. 15.1in [5] where $4 \mathrm{WD}$ tractive condition for firm soil $=0.78$ and tilled soil $=0.75$.

And for self-propelled machines that has rotary power. Power - takeoff (PTO) power required to power the implement from PTO shaft of the tractor or engine. Implement power take-off power can be calculated using eq. (7).

$$
P_{\text {pto }}=(a+b w+c C m)
$$

Where:

$P_{\text {pto }}=$ power-takeoff rotary power required by the implement, $\mathrm{kW}$,

$w=$ implement working width, $\mathrm{m}$,

$\mathrm{Cm}=$ material feed rate on wet basis, $\mathrm{t} / \mathrm{h}, a, b, c=$ machine spec. constants from Tab. 3 For some machines, drawbar power requirement must be added to the rotary power requirement to obtain the total power requirement.

V. Cost of equipment use

Equipment cost of use includes charges for ownership and operation cost. The ownership costs or fixed or overhead costs are usually independent of use but being owned which is termed as fixed cost like depreciation, shelter, interest on capital and inflation, insurance and taxes. Operation costs vary directly with the amount of use called variable cost like repair, maintenance, labour, timeliness, fuel, oil and lubricants, [7].

(a). Total annual ownership costs:

Generally speaking, equipment ownership costs include equipment depreciation, interest on the investment, and cost of taxes, insurance and housing or shelter of the equipment. Hence total annual costs can be expressed as follows using eq. (8) 


$$
C_{o S}=\frac{C o a}{P u}=\left(1-S_{v}\right)\left[\frac{i(1+i)^{L}}{(1+i)^{L}-1}\right]+\frac{k}{100}
$$

Where:

$C_{o s}=$ specific annual ownership costs, per year,

$C_{o a}$ (decimal) x purchase price = average annual ownership cost of machine,

$S_{v}=$ salvage value factor of machine at end of machine life year, L, decimal,

$L=$ machine life, year, $i$ - interest ratio, decimal,

$K=$ annual ownership cost of taxes, housing/shelter, and insurance: normally expressed as a percentage of purchase price, decimal.

Also, this can be estimated using eq. (9) [8].

$C_{o}=100\left[\frac{1-S v}{L}+\frac{1+S v}{2} i+k\right]$

Where:

$C_{o}=$ ownership cost in \%. $\mathrm{P}_{\mathrm{u}}(1+i)^{\mathrm{L}}$

\section{(b). Operating costs:}

Repair and maintenance cost

Repair and maintenance is to keep equipment operational due to wear, part failures, accidents and normal operational determination. Accumulated repair and maintenance costs at a typical field speed can be determined using eq. (10) [9].

$$
C_{r m}=(R F I) P u\left(\frac{t}{1000}\right)^{R F 2}
$$

Where:

$C_{r m}=$ accumulated repair and maintenance costs, $\mathrm{N}, R F 1$ and $R F 2$ are repair and maintenance factors (Tab. 3 in [9] and (Tab. 15.1 in [5],

$P u=$ purchase machine list price in current Naira. For rapid inflation rate, the original list price must be multiplied by $(1+i)^{n}$, where $\mathrm{i}$ is the average inflation rate and $\mathrm{n}$ is the age of machine.

$t=$ accumulated use of machine, $\mathrm{h}$.

To correct for inflation, the purchase price $(\mathrm{Pu})$ in equation above is multiplied by $(1+\mathrm{i})^{\mathrm{n}}$ i.e $\mathrm{Pu}=\mathrm{Pu}(1+\mathrm{i})^{\mathrm{n}}$, hence accumulated repair and maintenance costs vary from year to year. Average hourly cost of repair and maintenance can be estimated by estimating the total economic life of the machine in hours, using equation 19 to calculate the total repair and maintenance costs over the life of the machine and dividing the total economic life in hours. One can obtain the average repair and maintenance cost per hectare of area worked by the machine by dividing the average cost by machine capacity, $\mathrm{C}_{\mathrm{a}}$.

Example from equation above, with data in Tab. 15.1 shows that for tractor, total repair and maintenance costs over or divide by the life of a tractor is equal to the purchase price of the tractor.

\section{Fuel consumption}

Fuel consumption for diesel engine was calculated using eq. (11) [2]

$Q_{f}=0.226 P b d$

$Q_{\text {fav }}=0.305$ Ppto

Where:

$Q_{f}=$ fuel consumption, $1 / \mathrm{h}, \quad Q_{f a v}=$ average fuel consumption, $1 / \mathrm{h}$ 
Fuel consumption for a particular operation was calculated using eq. (12) [8].

$Q_{i}=Q_{S} P_{T}$

Where:

$Q_{i}=$ estimated fuel consumption for a particular operation, $1 / \mathrm{h}$,

$Q_{s}=$ specific fuel consumption for given tractor, $1 / \mathrm{kWh},[9]$.

\section{Costs of fuel and oil}

Any given operation per hectare fuel (or oil) cost was calculated using the following eqs. (13) and (14), [5] :

$C_{s}=\frac{P_{l} Q_{i}}{C_{a}}$

Where:

$C_{S}=$ per hectare fuel (oil) costs, $P_{l}=$ price of fuel (oil), $\mathrm{N} / 1$,

$Q_{i}$ - fuel (oil) consumed by engine, $1 / \mathrm{h}$,

$C_{a}=$ effective field capacity during the operation, ha/h.

$\left.S F C_{v}=3.91+2.64 X-0.263 \sqrt{(173}+738 X\right)$

If $X>0.856$, then $S F C_{v}=0.411 \mathrm{l} / \mathrm{kWh}$

Where:

$S F C_{v}=$ specific fuel consumption, volume basis, $1 / \mathrm{kWh}$,

$X=$ ratio of equivalent PTO power requirement to maximum available PTO power.

Usually, values of $X$ range between 0.2 for spraying operations to 0.85 for primary

tillage. Product of SFC and equivalent PTO power needed for the operation gives $\mathrm{Q}_{\mathrm{i}}$ and the estimated fuel consumption to perform the operation.

\section{Engine oil consumption}

This is estimated as $15 \%$ of total fuel cost [9] gives equation for estimating oil consumption of gasoline, diesel and LPG engines. The eq. (15) was used for diesel engines calculated:

$Q_{i o}=\frac{21.69+0.59 P_{r}}{1000}$

Where:

$Q_{i o}=$ oil consumption, $1 / \mathrm{h}, P_{r}=$ rated engine power, $\mathrm{kW}$.

Total cost of all lubricants can be estimated equal to $10 \%-15 \%$ of fuel costs.

\section{Labour cost}

Labour cost can be estimated for owner-operators from alternative opportunities for use of time. For hired operators, a constant hourly rate is appropriate and for two cases the charges should not be less than a typical community labour rate. Also a portion of the tractor ownership costs must be included in the cost of use of implements.

(c) Timeliness costs:

In agricultural operations, there is an optimum time of the year to perform some field operations and economic penalties are incurred if the operations are performed too early or too late. It is thus economically justifiable to increase machine costs through purchase of a machine of greater capacity when the larger machine will accomplish more timely work. Hence the term timeliness is important when carrying out machinery cost analyses. 
Timeliness cost was calculated by using eq. (16) [5].

$C_{t}=\frac{K_{t} A Y V}{Z T C a P w d}$

Where:

$C_{t}=$ timeliness cost, $\mathrm{N} / \mathrm{ha}$

$K_{t}=$ timeliness coefficient, fraction of annual crop value lost per day (Tab. 4)

$Y=$ crop yield, $\mathrm{t} / \mathrm{ha}$

$A=$ crop area, ha/year,

$V=$ crop value, $\mathrm{N} / \mathrm{t}$

$Z=2$ if operation commences or ends at optimum time, 4 if operation can be balanced evenly about optimum time,

$T$ = expected time available for field work, h/day,

$C_{a}$ - effective field capacity of machine, ha/h

Also timeliness cost can be estimated from a timeliness coefficient obtained from [9] clause 8. Annual timeliness cost for an operation was estimated using eq. (17).

$W=\frac{K_{3} A 2 Y V}{Z T C a P w d}$

Where:

$W=$ annual timeliness cost, $\mathrm{N}$,

$K_{3}$ - timeliness coefficient obtained from [9]

\section{Equipment Operational Planning and Control}

The tractor power and machinery size for the crop cultivation, crop establishment, weed control up to harvesting and transporting for the post- harvest processing store were determined to match each other in terms of row spacing and established tramline to reduce long time soil compaction problem, [10]. The headland or trace size for appropriate connected tractor and implement length to reduce turning time must be put in-place for each block of field.A well- drawn cropping field operations calendar was very important for crop and operational sequencing and be put in-place since the operations are overlapping with multi-periods. Resources like fuel and oil, equipment spare parts, fertilizer, insecticides, herbicides and their availability are limiting factors to be considered [11]

\section{RESULTS AND DISCUSSION}

Based on agricultural field operational planning factors like soil, weather and environmental conditions, appropriate implement matched with tractor calculations were carried out to obtain Tab. 1, Tab.1.1; Tab. 2., Tab. 2.1. and Tab.3.

Tab.1., Tab.1.1., shows the values of each implement field capacity it in allotted time available, actual number of implement/tractor required, ownership and operational costs. Tab.2., and Tab.2.1., show the same calculated cost values of pool of excess implements from which choice could make if need be while Tab.3 is similar calculation for selfpropelled equipment for earth works like land clearing/development, road, drainage, irrigation and dyke construction/maintenance works. 
From fleet of available prime mover, tractor in the sugar cane plantation, total power required to power the implements were determined for 4,770 ha of sugar cane cultivation, harvesting and transporting operations. Also appropriate earthmoving and earthwork equipment for road, irrigation and drainage work were determined.

As part of the recommendation, during the planned equipment downtime, major repairs and maintenance are to be carried out before critical field operations' period to improve pre-field and in-field efficiency, [2].

To improve machinery performance efficiency, [10], proper breakdowns communication reporting and daily record of every equipment operational record keeping will go a long way to make the machinery selected function well within the determined system.

The company, most of the time, has being responsible for the community road maintenance. Fertilizer and chemical applications are manually and knapsack applied respectively, hence so far, it has not started polluting the environment. Also waste water from the factory is being treated. hence not affecting stream water for now. In future when the company's operation will be fully mechanized, additional safety precautions/measures to control environmental and air pollution must be put in place.

Tab.4., is the cropping calendar of 4,770 ha which was based on crop cultivation operation sequence, soil type and condition, weather condition and Staff public holiday within the cropping season.

With this, the machinery power requirement, optimum size and number of equipment were determined based on total area under cultivation per season. Cropping field operations calendar shows that crop and operational sequencing is very important and hence thereby recommended to be put in-place since the operations are overlapping with multi-periods with peak periods of $1,332 \mathrm{~h} /$ month in November to 1,512 h/month in February. There must be adequate machinery management from November to April of the following year if the operational target of cultivating 4,770 ha of sugar cane with the fleet of the equipment and time available must be met as in Tab. 1.; Tab.1.1. and Tab. 2., Tab.2.1. 
Adisa et al.: Crop Machinery Management System.../Agr. Eng. (2021/4).97-120

109

Table 1. Recommended Machinery and Capacity Operation Requirement for Sunti Sugar cane 4,770 ha

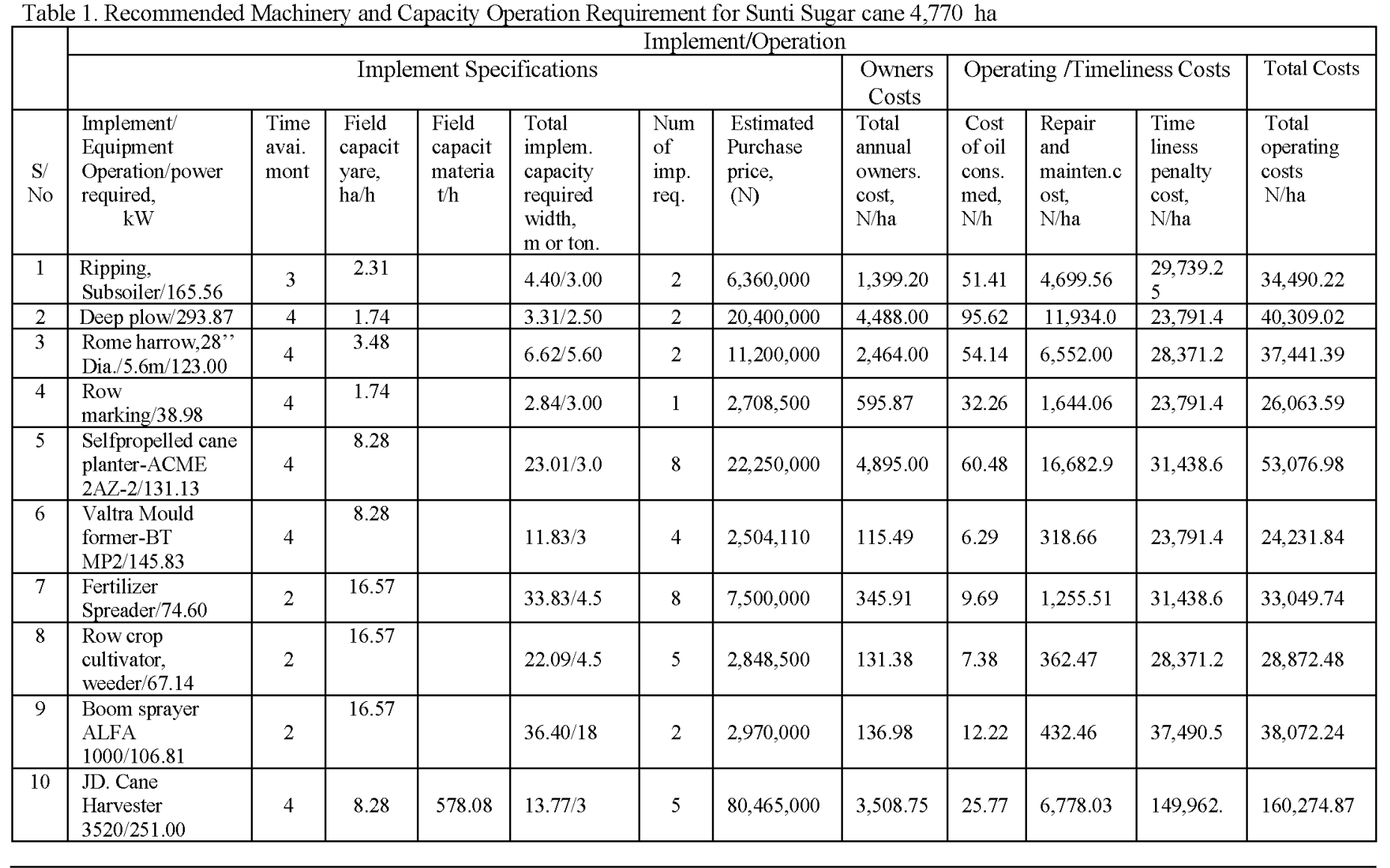


Adisa i sar.: Sistem upravljanja usevom.../Polj. Tehn. (2021/4). 97-120

\begin{tabular}{|c|c|c|c|c|c|c|c|c|c|c|c|c|}
\hline \multicolumn{13}{|c|}{ Continued Table 1} \\
\hline 11 & $\begin{array}{l}\text { JD Cane loader } \\
6068 \mathrm{~T} / 138.00 \\
\end{array}$ & 4 & 8.89 & 578.08 & $\begin{array}{l}333,000 / 40 \\
\text { ton } / \mathrm{h}\end{array}$ & 13 & $51,198,000$ & $10,649.1$ & 62.21 & $4,636.80$ & $69,864.3$ & $85,212.53$ \\
\hline 12 & $\begin{array}{l}\text { Cane wagon } \\
\text { transporter/72.76 }\end{array}$ & 4 & 8.89 & 578.08 & $\begin{array}{l}333,000 / 15 \\
\text { ton/load }\end{array}$ & 33 & $5,775,000$ & 251.82 & 7.99 & 959.50 & $69,864.3$ & $71,083.65$ \\
\hline 13 & $\begin{array}{l}\text { Cane stubble } \\
\text { shaver/ratoon } \\
\text { manager/86.27 }\end{array}$ & $\begin{array}{l}\text { As } \\
\text { req. }\end{array}$ & 1.50 & & & $\begin{array}{l}\text { As } \\
\text { req }\end{array}$ & $2,298,407$ & $1,011.30$ & 45.50 & $6,870.14$ & $35,491.1$ & $43,418.04$ \\
\hline 14 & $\begin{array}{l}\text { Sugar cane sett } \\
\text { cutter/ } \\
\text { chopper/ } 65.52 \\
\end{array}$ & $\begin{array}{l}\text { As } \\
\text { req. }\end{array}$ & 5.55 & & & $\begin{array}{l}\text { As } \\
\text { req }\end{array}$ & $44,787,727$ & $18,631.7$ & 35.14 & $52,934.5$ & $12,065.6$ & $83,667.03$ \\
\hline 15 & $\begin{array}{l}\text { Bowser- FKWT } \\
3000 \mathrm{~L} / 52.20 \\
\end{array}$ & $\begin{array}{c}\text { As } \\
\text { req. }\end{array}$ & $\begin{array}{c}3000 \mathrm{~L} / \\
\text { load }\end{array}$ & & $\begin{array}{l}3000 \mathrm{~L} / \\
\text { load }\end{array}$ & $\begin{array}{l}\text { As } \\
\text { req }\end{array}$ & $2,385,000$ & 524.70 & 30.53 & $1,030.32$ & & $1,585.55$ \\
\hline 16 & $\begin{array}{l}\text { Cane loader } \\
\text { BM100/74.60 }\end{array}$ & $\begin{array}{c}\text { As } \\
\text { req. }\end{array}$ & 8.89 & 578.08 & & $\begin{array}{l}\text { As } \\
\text { req }\end{array}$ & $25,000,000$ & $5,200.00$ & 38.02 & $10,800.0$ & $69,864.3$ & $85,902.36$ \\
\hline 17 & $\begin{array}{l}\text { Cane loader } \\
\text { Bell/49.00 }\end{array}$ & $\begin{array}{l}\text { As } \\
\text { req. }\end{array}$ & 5.39 & 350.33 & & $\begin{array}{l}\text { As } \\
\text { req }\end{array}$ & $24,000,000$ & $4,992.00$ & 29.38 & $10,368.0$ & 115,230 . & $130,620.17$ \\
\hline 18 & $\begin{array}{l}\text { Cane loader } \\
1850 / 78.00 \\
\end{array}$ & $\begin{array}{c}\text { As } \\
\text { req. }\end{array}$ & 8.89 & 578.08 & & $\begin{array}{l}\text { As } \\
\text { req. }\end{array}$ & $40,000,000$ & $8,320.00$ & 39.17 & $17,280.0$ & $69,864.3$ & $95,503.51$ \\
\hline
\end{tabular}

Note please: Nigeria Naira to USD at time of study was N385 to \$1. 


\begin{tabular}{|c|c|c|c|c|c|c|c|c|}
\hline & \multicolumn{7}{|c|}{ Tractor/Prime mover } \\
\hline & & \multicolumn{2}{|c|}{ Power Ratings } & \multirow{2}{*}{$\begin{array}{l}\begin{array}{l}\text { Owner } \\
\text { ship Costs }\end{array} \\
\text { Total } \\
\text { annual } \\
\text { ownership } \\
\text { cost, N/ha }\end{array}$} & \multicolumn{3}{|c|}{ Operating Costs } & \multirow{2}{*}{$\begin{array}{l}\text { Total Costs } \\
\text { Total } \\
\text { operating } \\
\text { costs } \\
\mathrm{N} / \mathrm{ha}\end{array}$} \\
\hline $\mathrm{S} / \mathrm{No}$ & $\begin{array}{l}\text { Implement/ } \\
\text { Equipment } \\
\text { Operation/power } \\
\text { required, } \mathrm{kW}\end{array}$ & $\begin{array}{l}\text { Equipment/ } \\
\text { power, } \\
\mathrm{kW}\end{array}$ & $\begin{array}{l}\text { Estimated } \\
\text { Purchase } \\
\text { price, } \\
\text { (N) }\end{array}$ & & $\begin{array}{l}\text { Cost of } \\
\text { fuel } \\
\text { cons., } \\
\text { N/ha }\end{array}$ & $\begin{array}{l}\text { Cost } \\
\text { of oil } \\
\text { cons. } \\
\text { N/ha }\end{array}$ & $\begin{array}{l}\text { Repair and } \\
\text { maintena. } \\
\text { cost, } \\
\mathrm{N} / \mathrm{h}\end{array}$ & \\
\hline 1. & $\begin{array}{l}\text { Ripping, } \\
\text { Subsoiler/165.56 } \\
\end{array}$ & $\begin{array}{l}\text { J. D. tract. } \\
7225 \mathrm{~J} / 168.00 \\
\end{array}$ & $48,000,000$ & $10,416.00$ & $2,807.14$ & 52.27 & $20,736.00$ & $33,959.14$ \\
\hline 2. & Deep plow/293.87 & $\begin{array}{l}\text { J.D.Tract, } \\
8970 / 298.00 \\
\end{array}$ & $88,000,000$ & $19,096.00$ & $7,456.32$ & 114.05 & $38,016.00$ & $64,682.37$ \\
\hline 3. & $\begin{array}{l}\text { Rome harrow, } 28 " \\
\text { Dia./5.6m/123.00 }\end{array}$ & $\begin{array}{l}\text { Valtra med. } \\
\text { tractor, } \\
\text { T171/134.00 }\end{array}$ & $30,000,000$ & $6,517.50$ & $3,359.23$ & 58.18 & $12,960.00$ & $22,894.91$ \\
\hline 4. & Row marking $/ 38.98$ & $\begin{array}{l}\text { J.D. tract. } \\
2650 / 58.20\end{array}$ & $13,000,000$ & $2,886.00$ & 724.03 & 32.26 & $5,616.00$ & $9,258.29$ \\
\hline 5. & $\begin{array}{l}\text { Selfpropelled cane } \\
\text { planter } \\
\text { ACME-2AZ2/131.13 }\end{array}$ & $\begin{array}{l}\text { Valtra Tract. } \\
\text { T191/141.00 }\end{array}$ & $35,000,000$ & $7,603.75$ & $3,162.24$ & 60.48 & $15,120.00$ & $25,946.47$ \\
\hline 6. & $\begin{array}{l}\text { Valtra Mould } \\
\text { former } \\
\text { BT-MP2/145.83 }\end{array}$ & $\begin{array}{l}\text { J. D.Tract. } \\
4960 / 149.00\end{array}$ & $45,000,000$ & $1,962.26$ & 922.75 & 13.31 & $4,075.47$ & $6,973.79$ \\
\hline 7. & $\begin{array}{l}\text { Fertilizer } \\
\text { Spreader } / 74.60\end{array}$ & $\begin{array}{l}\text { Valtra Tract. } \\
\text { BM- } 125 \mathrm{i} / 98.40\end{array}$ & $23,480,000$ & $1,026.25$ & 420.72 & 9.69 & $2,126.49$ & $3,583.15$ \\
\hline 8. & $\begin{array}{l}\text { Row crop cultivator, } \\
\text { weeder } / 67.14\end{array}$ & $\begin{array}{l}\text { J.D.Tractor } \\
3350 / 74.60 \\
\end{array}$ & $17,000,000$ & 791.19 & $1,025.11$ & 432.78 & $1,539.62$ & $3,788.70$ \\
\hline 9. & $\begin{array}{l}\text { Boom sprayer } \\
\text { ALFA 1000/106.81 }\end{array}$ & $\begin{array}{l}\text { Valtra Tract. } \\
\text { T171/134.00 }\end{array}$ & $30,000,000$ & $1,366.35$ & 412.73 & 12.22 & $2,716.98$ & $4,508.28$ \\
\hline 10. & $\begin{array}{l}\text { JD. Cane Harvester } \\
3520 / 251.00\end{array}$ & $\begin{array}{l}\text { Self prop./ } \\
251.00\end{array}$ & $80,465,000$ & $3,508.75$ & $2,048.41$ & 25.77 & $6,778.03$ & $12,360.96$ \\
\hline
\end{tabular}


Adisa i sar.: Sistem upravljanja usevom.../Polj. Tehn. (2021/4). 97-120

\begin{tabular}{|c|c|c|c|c|c|c|c|c|}
\hline \multicolumn{9}{|c|}{ Continued Table 1.1 } \\
\hline 11. & $\begin{array}{l}\text { JD Cane loader- } \\
6068 \mathrm{~T} / 138.00\end{array}$ & $\begin{array}{l}\text { JD Cane } \\
\text { loader } 6068 \mathrm{~T} / 13 \\
8.00\end{array}$ & $51,198,000$ & $10,649.18$ & $1,931.93$ & 62.21 & $22,117.54$ & $34,760.86$ \\
\hline 12. & $\begin{array}{l}\text { Cane wagon } \\
\text { transporter/72.76 }\end{array}$ & $\begin{array}{l}\text { J.D. Tract. } \\
3350 / 74.60\end{array}$ & $17,000,000$ & 791.19 & 366.27 & 7.99 & $1,539.62$ & $2,705.07$ \\
\hline 13. & $\begin{array}{l}\text { Cane stubble } \\
\text { shaver/ratoon } \\
\text { manager } / 86.27\end{array}$ & $\begin{array}{l}\text { Valtra Tract. } \\
\text { BM 125i/98.40 }\end{array}$ & $23,480,000$ & $9,790.38$ & $2,108.16$ & 46.08 & $20,286.72$ & $32,231.34$ \\
\hline 14. & $\begin{array}{l}\text { Sugar cane sett } \\
\text { cutter/ chopper/65.52 }\end{array}$ & $\begin{array}{l}\text { J.D. Tract. } \\
3050 / 67.60\end{array}$ & $44,787,727$ & $18,631.70$ & $1,546.56$ & 35.14 & $52,934.55$ & $73,147.95$ \\
\hline 15. & $\begin{array}{l}\text { Bowser- FKWT } \\
3000 \mathrm{~L} / 52.20\end{array}$ & $\begin{array}{l}\text { John Deere } \\
\text { tractor, } \\
2650 / 58.20\end{array}$ & $13,000,000$ & $2,886.00$ & $1,594.94$ & 30.53 & $5,616.00$ & $10,127.47$ \\
\hline 16. & $\begin{array}{l}\text { Cane loader. } \\
\text { BM100/74.60 }\end{array}$ & $\begin{array}{l}\text { Cane loader } \\
\text { BM100/74.60 }\end{array}$ & $25,000,000$ & $5,200.00$ & $2,083.97$ & 38.02 & $10,800.00$ & $18,121.99$ \\
\hline 17. & $\begin{array}{l}\text { Cane loader. } \\
\text { Bell/49.00 }\end{array}$ & $\begin{array}{l}\text { Cane loader } \\
\text { Bell/49.00 } \\
\end{array}$ & $24,000,000$ & $4,992.00$ & 824.26 & 29.38 & $10,368.00$ & $16,213.64$ \\
\hline 18. & $\begin{array}{l}\text { Cane loader. } \\
1850 / 78.00\end{array}$ & $\begin{array}{l}\text { Cane loader } \\
1850 / 78.00 \\
\end{array}$ & $40,000,000$ & $8,320.00$ & $2,139.26$ & 39.17 & $17,280.00$ & $27,778.43$ \\
\hline
\end{tabular}

Note please: Nigeria Naira to USD at time of study was N385 to \$1. 
Table 2. Capacity and Cost of Field Equipment Operation Requirement of Available Additional Machinery from which choice could be made

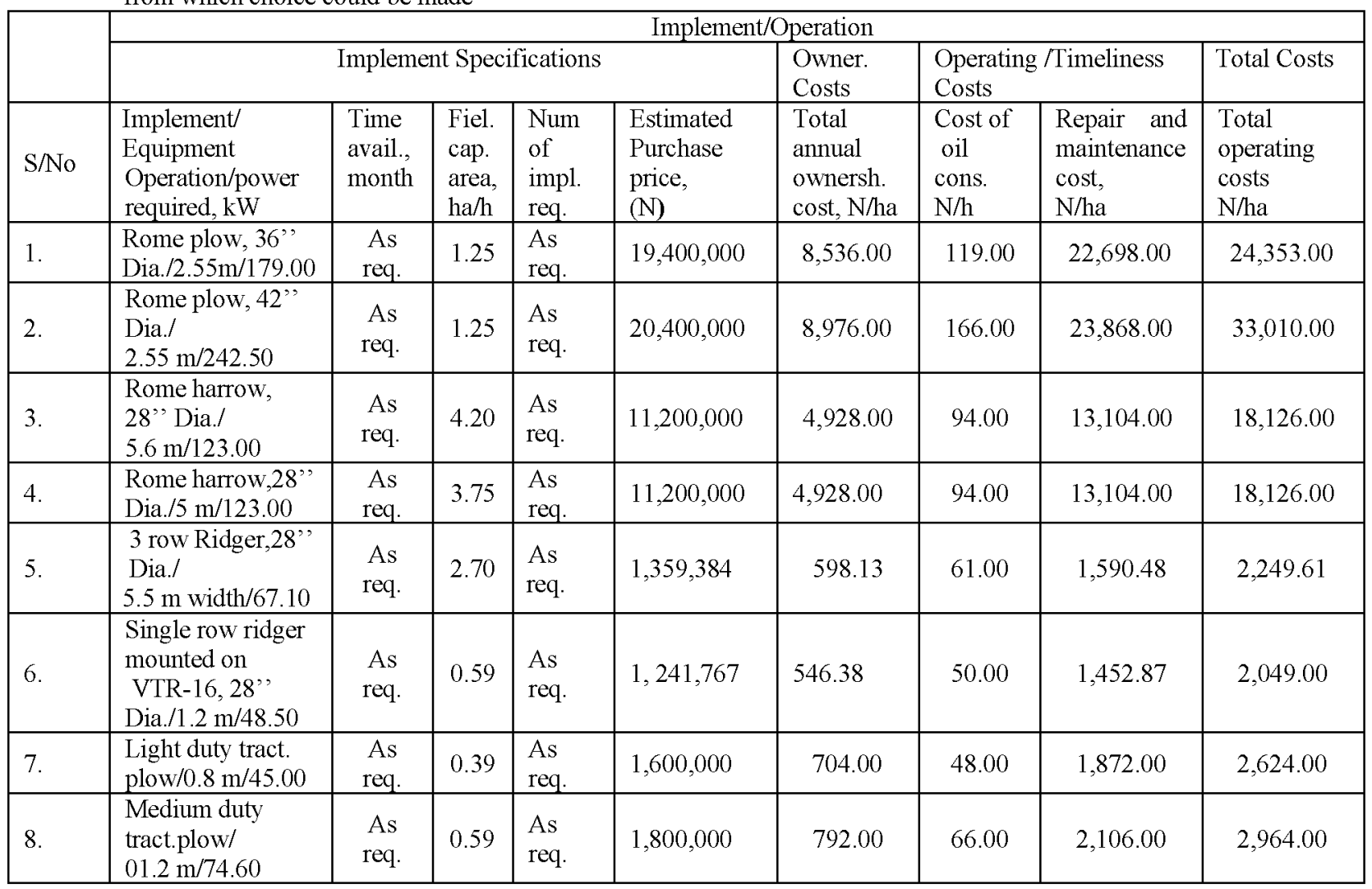


Adisa i sar.: Sistem upravljanja usevom.../Polj. Tehn. (2021/4). 97-120

\begin{tabular}{|l|l|c|c|c|c|c|c|c|c|}
\hline \multicolumn{1}{c}{ Continued Table 2.} \\
\hline 9. & $\begin{array}{l}\text { Heavy duty tract. } \\
\text { plow/1.5 m/97.00 }\end{array}$ & $\begin{array}{c}\text { As } \\
\text { req. }\end{array}$ & 0.74 & $\begin{array}{c}\text { As } \\
\text { req. }\end{array}$ & $2,200,000$ & 968.00 & 79.00 & $2,574.00$ & $3,621.00$ \\
\hline 10. & $\begin{array}{l}\text { Light duty tract. } \\
\text { harrow } \\
\text { 13.0 } \mathrm{m} / 45.00\end{array}$ & $\begin{array}{c}\text { As } \\
\text { req. }\end{array}$ & 2.25 & $\begin{array}{c}\text { As } \\
\text { req. }\end{array}$ & $2,000,000$ & 880.00 & 48.00 & $2,340.00$ & $3,268.00$ \\
\hline 11. & $\begin{array}{l}\text { Medium duty } \\
\text { tract. harrow/ } \\
5.0 \mathrm{~m} / 74.60\end{array}$ & $\begin{array}{c}\text { As } \\
\text { req. }\end{array}$ & 3.75 & $\begin{array}{c}\text { As } \\
\text { req. }\end{array}$ & $2,400,000$ & $1,056.00$ & 66.00 & $2,808.00$ & $3,930.00$ \\
\hline 12. & $\begin{array}{l}\text { Heavy duty tract. } \\
\text { harrow/ } \\
6.5 \mathrm{~m} / 97.00\end{array}$ & $\begin{array}{c}\text { As } \\
\text { req. }\end{array}$ & 4.88 & $\begin{array}{c}\text { As } \\
\text { req. }\end{array}$ & $3,000,000$ & $1,320.00$ & 79.00 & $3,510.00$ & $4,909.00$ \\
\hline
\end{tabular}

Note please: Nigeria Naira to USD at time of study was N385 to $\$ 1$.

\begin{tabular}{|c|c|c|c|c|c|c|c|}
\hline \multirow{3}{*}{ S/No } & \multicolumn{7}{|l|}{ Tractor/Prime mover } \\
\hline & \multicolumn{2}{|l|}{ Power Ratings } & \multirow{2}{*}{$\begin{array}{l}\text { Ownership Costs } \\
\text { Total annual } \\
\text { ownership cost, } \\
\text { N/ha }\end{array}$} & \multicolumn{3}{|c|}{ Operating Costs } & \multirow{2}{*}{$\begin{array}{l}\text { Total Costs } \\
\text { Total operating } \\
\text { costs } \\
\text { N/ha }\end{array}$} \\
\hline & $\begin{array}{l}\text { Implement/Equipment } \\
\text { Operation/power required, } \mathrm{kW}\end{array}$ & $\begin{array}{l}\text { Estimated } \\
\text { Purchase price, } \\
\text { (N) }\end{array}$ & & $\begin{array}{l}\text { Cost of fuel } \\
\text { con. } \\
\text { N/ha }\end{array}$ & $\begin{array}{l}\text { Cost of } \\
\text { oil } \\
\text { cons. } \\
\text { N/ha }\end{array}$ & $\begin{array}{l}\text { Repair and } \\
\text { maintence } \\
\text { cost, } \\
\mathrm{N} / \mathrm{h}\end{array}$ & \\
\hline 1. & $\begin{array}{l}\text { Rome plow,36" } \\
\text { Dia./2.55m/179.00 }\end{array}$ & $68,000,000$ & $29,512.00$ & $13,095.00$ & 184.00 & $58,752.00$ & $101,543.00$ \\
\hline 2. & $\begin{array}{l}\text { Rome plow, } 42 \text { " } \\
\text { Dia./2.55 m/242.50 }\end{array}$ & $68,000,000$ & $29,512.00$ & $13,095.00$ & 184.00 & 58752.00 & $101,543.00$ \\
\hline 3. & $\begin{array}{l}\text { Rome harrow, } 2{ }^{\prime \prime} \\
\text { Dia. } / 5.6 \mathrm{~m} / 123.00\end{array}$ & $30,000,000$ & $13,035.00$ & $5,832.00$ & 101.00 & $25,920.00$ & $44,888.00$ \\
\hline 4. & $\begin{array}{l}\text { Rome harrow, } 28 \text { " } \\
\text { Dia. } / 5 \mathrm{~m} / 123.00\end{array}$ & $30,000,000$ & $13,035.00$ & $5,832.00$ & 101.00 & $25,920.00$ & $44,888.00$ \\
\hline 5. & $\begin{array}{l}3 \text { row Ridger, } 28 \text { ", } \\
\text { Dia. } / 5.5 \mathrm{~m} \text { width } / 67.10\end{array}$ & $17,000,000$ & $7,548.00$ & 3,576 & 66.00 & $14,688.00$ & $25,878.00$ \\
\hline
\end{tabular}


Adisa et al.: Crop Machinery Management System.../Agr. Eng. (2021/4).97-120

115

\begin{tabular}{|c|c|c|c|c|c|c|c|}
\hline \multicolumn{8}{|c|}{ Continued Table 2.1 . } \\
\hline 6. & $\begin{array}{l}\text { Single row ridger mounted on } \\
\text { VTR-16, } 28^{\prime \prime} \\
\text { Dia. } / 1.2 \mathrm{~m} / 48.50\end{array}$ & $13,000,000$ & $5,772.00$ & $2,769.00$ & 56.00 & $11,232.00$ & $19,829.00$ \\
\hline 7. & $\begin{array}{l}\text { Light duty tract. } \\
\text { plow/ } 0.8 \mathrm{~m} / 45.00\end{array}$ & $13,000,000$ & $5,772.00$ & $2,769.00$ & 56.00 & $11,232.00$ & $19,829.00$ \\
\hline 8. & $\begin{array}{l}\text { Medium duty tract. } \\
\text { plow/1.2 m/74.60 }\end{array}$ & $18,000,000$ & $7,488.00$ & $4,071.00$ & 72.00 & $15,552.00$ & $27,183.00$ \\
\hline 9. & $\begin{array}{l}\text { Heavy duty tract. } \\
\text { plow } 1.5 \mathrm{~m} / 97.00\end{array}$ & $23,480,000$ & $9,790.38$ & $3,561.00$ & 80.00 & $20,286.72$ & $33,717.72$ \\
\hline 10. & $\begin{array}{l}\text { Light duty tract. } \\
\text { harrow } / 3.0 \mathrm{~m} / 45.00\end{array}$ & $13,000,000$ & $5,772.00$ & $2,769.00$ & 56.00 & $11,232.00$ & $19,829.00$ \\
\hline 11. & $\begin{array}{l}\text { Medium duty tract. harrow } / 5.0 \\
\mathrm{~m} / 74.60\end{array}$ & $18,000,000$ & $7,488.00$ & $4,071.00$ & 72.00 & $15,552.00$ & $27,183.00$ \\
\hline 12. & $\begin{array}{l}\text { Heavy duty tract. } \\
\text { harrow/ } 6.5 \mathrm{~m} / 97.00\end{array}$ & $23,480,000$ & $9,790.38$ & $3,561.00$ & 80.00 & $20,286.72$ & $33,718.10$ \\
\hline
\end{tabular}

Table 3. Sunti Sugar cane 4,770 ha Recommended Machinery Capacity and Cost of Self-propelled Field Equipment Operation Requirement for Earthworks

\begin{tabular}{|c|c|c|c|c|c|c|c|c|c|}
\hline & \multicolumn{9}{|c|}{ Implement } \\
\hline & \multicolumn{4}{|c|}{ Implement Specifications } & \multirow{2}{*}{$\begin{array}{c}\text { Ownership } \\
\text { Costs } \\
\text { Total annual } \\
\text { ownership } \\
\text { cost, } 1000 \text {, } \\
\text { N }\end{array}$} & \multicolumn{3}{|c|}{ Operating /Timeliness Costs } & \multirow{2}{*}{$\begin{array}{c}\text { Total Costs } \\
\text { Total } \\
\text { cost, } \\
\mathrm{N} / \mathrm{h}\end{array}$} \\
\hline S/No & $\begin{array}{l}\text { Implement/Equipment/ } \\
\text { power required, } \mathrm{kW}\end{array}$ & $\begin{array}{c}\text { Eq. cap., } \\
\text { area. } \\
\text { ha/h }\end{array}$ & $\begin{array}{l}\text { Number } \\
\text { of imp. } \\
\text { req. }\end{array}$ & $\begin{array}{c}\text { Estimated } \\
\text { Purchase } \\
\text { price, } \\
(\mathrm{N})\end{array}$ & & $\begin{array}{c}\text { Cost of } \\
\text { fuel } \\
\text { consumed, } \\
\mathrm{N} / \mathrm{h}\end{array}$ & $\begin{array}{c}\text { Cost of } \\
\text { oil } \\
\text { cons., } \\
\text { N/h } \\
\end{array}$ & $\begin{array}{l}\text { Repair and } \\
\text { maint. } \\
\text { cost, } \\
\mathrm{N} \\
\end{array}$ & \\
\hline 1. & $\begin{array}{l}\text { Cat. Bulldozer } \\
\mathrm{D} 7 \mathrm{G} / 164.00\end{array}$ & & $\begin{array}{r}\text { As } \\
\text { required } \\
\end{array}$ & $150,000,000$ & $31,200.00$ & $7,773.00$ & 119.00 & $115,200.00$ & $154,292.00$ \\
\hline 2. & $\begin{array}{l}\text { Cat. Bulldozer } \\
\text { D8R/245.00 } \\
\end{array}$ & & $\begin{array}{r}A s \\
\text { required } \\
\end{array}$ & $200,000,000$ & $41,600.00$ & $11,694.00$ & 166.00 & $153,600.00$ & $207,060.00$ \\
\hline
\end{tabular}


Adisa i sar.: Sistem upravljanja usevom.../Polj. Tehn. (2021/4). 97-120

\begin{tabular}{|c|c|c|c|c|c|c|c|c|c|}
\hline & Continued Table 3. & & & & & & & & \\
\hline 3. & $\begin{array}{l}\text { Amphibious excavator } \\
\text { SWEA220/69.60 }\end{array}$ & 0.10 & $\begin{array}{l}\quad \mathrm{As} \\
\text { required } \\
(50 \mathrm{ha} / \mathrm{yr})\end{array}$ & $48,147,500$ & $10,014.68$ & $2,820.00$ & 63.00 & $36,977.28$ & $49,874.96$ \\
\hline 4. & $\begin{array}{l}\text { Ditch witch implement } \\
\text { RT55/42.00 }\end{array}$ & 0.07 & \begin{tabular}{c}
\multicolumn{1}{c}{$\mathrm{As}$} \\
required \\
$(25 \mathrm{ha} / \mathrm{yr})$
\end{tabular} & $25,600,000$ & $5,324.80$ & $1,491.00$ & 47.00 & $11,059.20$ & $17,922.20$ \\
\hline 5. & \begin{tabular}{|l|} 
Excavator \\
$325 \mathrm{C} / 141.00$
\end{tabular} & 0.08 & $\begin{array}{c}\mathrm{As} \\
\text { required } \\
(25 \mathrm{ha} / \mathrm{yr})\end{array}$ & $60,000,000$ & $12,480.00$ & $6,093.00$ & 105.00 & $46,080.00$ & $64,758.00$ \\
\hline 6. & $\begin{array}{l}\text { Excavator } \\
\text { 320L/97.00 }\end{array}$ & 0.06 & $\begin{array}{c}\text { As } \\
\text { required } \\
(25 \mathrm{ha} / \mathrm{yr})\end{array}$ & $65,000,000$ & $13,520.00$ & $4,617.00$ & 79.00 & $49,920.00$ & $68,136.00$ \\
\hline 7. & $\begin{array}{l}\text { Excavator } \\
\text { JS2052C/106.00 }\end{array}$ & 0.07 & $\begin{array}{c}\quad \mathrm{As} \\
\text { required } \\
(25 \mathrm{ha} / \mathrm{yr})\end{array}$ & $55,000,000$ & $11,440.00$ & $4,542.00$ & 84.00 & $42,240.00$ & $58,306.00$ \\
\hline 8. & $\begin{array}{l}\text { Motor grader } \\
140 \mathrm{H} / 138.00\end{array}$ & & $\begin{array}{c}\text { As } \\
\text { required }\end{array}$ & $103,846,000$ & $21,599.97$ & $6,567.00$ & 103.00 & $79,753.73$ & $108,023.70$ \\
\hline 9. & $\begin{array}{l}\text { Compactor } \\
\text { VM1 16drum/85.00 }\end{array}$ & 1.47 & $\begin{array}{l}\quad \Lambda s \\
\text { require } \\
(10 \mathrm{ha} / \mathrm{yr})\end{array}$ & $29,500,000$ & $6,136.00$ & $4,047.00$ & 72.00 & $12,744.00$ & $22,999.00$ \\
\hline 10. & $\begin{array}{l}\text { Paywheel loader } \\
432 Z X / 112.00 \\
\end{array}$ & 1.81 & $\begin{array}{c}\mathrm{As} \\
\text { required }\end{array}$ & $49,000,000$ & $10,192.00$ & $5,289.00$ & 88.00 & $21,168.00$ & $36,737.00$ \\
\hline 11. & $\begin{array}{l}\text { Backhoe loader } \\
\text { JCB 3DX/68.60 } \\
\end{array}$ & 1.76 & $\begin{array}{r}\text { As } \\
\text { required }\end{array}$ & $45,000,000$ & $9,360.00$ & $3,264.00$ & 62.00 & $19,440.00$ & $32,126.00$ \\
\hline 12. & $\begin{array}{l}\text { Backhoe loader } \\
\text { JCB 3CX/55.00 }\end{array}$ & 1.70 & $\begin{array}{c}A s \\
\text { required }\end{array}$ & $40,000,000$ & $8,320.00$ & $2,619.00$ & 54.00 & $17,280.00$ & $28,273.00$ \\
\hline 13. & $\begin{array}{l}\text { Backhoe loader } \\
\text { JCB 4CX/74.60 }\end{array}$ & 1.74 & $\begin{array}{r}\mathrm{As} \\
\text { required }\end{array}$ & $48,000,000$ & $9,984.00$ & $3,060.00$ & 66.00 & $20,736.00$ & $33,846.00$ \\
\hline
\end{tabular}

Note please: Nigeria Naira to USD at time of study was N385 to \$1. 


\begin{tabular}{|c|c|c|c|c|c|c|c|c|c|c|c|c|c|c|}
\hline $\begin{array}{c}\mathrm{S} / \mathrm{N} \\
0\end{array}$ & Operation & $\begin{array}{l}\text { Cover. } \\
\text { area, } \\
\text { ha }\end{array}$ & $\begin{array}{c}\text { Oct., } \\
\text { h }\end{array}$ & $\begin{array}{c}\text { Nov., } \\
\mathrm{h}\end{array}$ & $\begin{array}{c}\text { Dec., } \\
\text { h }\end{array}$ & $\begin{array}{c}\text { Jan., } \\
\mathrm{h}\end{array}$ & $\begin{array}{c}\text { Feb., } \\
\mathrm{h}\end{array}$ & $\begin{array}{c}\text { Mar } \\
. h\end{array}$ & $\begin{array}{c}\text { Apr., } \\
\mathrm{h}\end{array}$ & $\begin{array}{c}\text { May, } \\
\mathrm{h}\end{array}$ & $\begin{array}{c}\text { June } \\
\mathrm{h}\end{array}$ & $\begin{array}{c}\text { July, } \\
\mathrm{h}\end{array}$ & $\begin{array}{c}\text { Aug., } \\
h\end{array}$ & $\begin{array}{c}\text { Sept., } \\
\mathrm{h}\end{array}$ \\
\hline 1. & Ripping & 1,000 & 72 & 144 & 72 & 144 & & & & & & & & \\
\hline 2. & Deep plow & 1,000 & 36 & 144 & 72 & 144 & 144 & 36 & & & & & & \\
\hline 3. & Harrow & 1,000 & & 144 & 72 & 144 & 144 & 72 & & & & & & \\
\hline 4. & Row marking & 1,000 & & 144 & 72 & 144 & 144 & 72 & & & & & & \\
\hline 5. & Cane planting & 1,000 & & 144 & 72 & 144 & 144 & 72 & & & & & & \\
\hline 6. & $\begin{array}{l}\text { Bedforming/ } \\
\text { earth-up }\end{array}$ & 4,770 & & 72 & 72 & 144 & 144 & 144 & & & & & & \\
\hline 7. & $\begin{array}{l}\text { Ratoon cane } \\
\text { stubble } \\
\text { shaver/manager }\end{array}$ & 500 & & 72 & 72 & 72 & 72 & & & & & & & \\
\hline 8. & $\begin{array}{l}\text { Fertilizer } \\
\text { broadcasting }\end{array}$ & 4,770 & & 36 & 36 & 36 & 36 & 36 & 36 & 36 & 36 & & & \\
\hline 9. & $\begin{array}{l}\text { Herbicide } \\
\text { spraying }\end{array}$ & 4,770 & & & 36 & 36 & 36 & 36 & 36 & 36 & 36 & 36 & & \\
\hline 10. & $\begin{array}{l}\text { Row crop } \\
\text { cultivating/ } \\
\text { weeding }\end{array}$ & 4,770 & & & & 72 & 72 & 72 & 72 & & & & & \\
\hline 11. & Irrigation/drainage & 4,770 & & $\begin{array}{l}\text { As } \\
\text { req. }\end{array}$ & $\begin{array}{l}\text { As } \\
\text { req. }\end{array}$ & $\begin{array}{l}\text { As } \\
\text { req. }\end{array}$ & $\begin{array}{l}\text { As } \\
\text { req. }\end{array}$ & $\begin{array}{l}\text { As } \\
\text { req. }\end{array}$ & $\begin{array}{l}\text { As } \\
\text { req. }\end{array}$ & $\begin{array}{l}\text { As } \\
\text { req. }\end{array}$ & $\begin{array}{l}\text { As } \\
\text { req. }\end{array}$ & $\begin{array}{l}\text { As } \\
\text { req. }\end{array}$ & $\begin{array}{l}\text { As } \\
\text { req. }\end{array}$ & $\begin{array}{l}\text { As } \\
\text { req. }\end{array}$ \\
\hline 12. & Cane harvesting & 4,770 & & 144 & 72 & 144 & 144 & 72 & & & & & & \\
\hline 13. & Cane loading & 4,770 & & 144 & 72 & 144 & 144 & 72 & & & & & & \\
\hline 14. & Cane transporting & 4,770 & & 144 & 72 & 144 & 144 & 72 & & & & & & \\
\hline & & & 108 & 1,332 & 792 & 1,512 & 1,368 & 756 & 144 & 72 & 72 & 36 & & \\
\hline
\end{tabular}




\section{CONCLUSIONS}

This study was able to determine appropriate tractor power matched with machinery for the crop cultivation, crop establishment, weed control up to harvesting and transporting for the post- harvest processing store for 4,770 ha of sugar cane production. This was made possible based on agricultural field operational planning factors like soil, weather and environmental condition, implement and appropriate matching tractor calculations. A well- drawn cropping field operations calendar was very important for crop and operational sequencing and hence recommended since the operations are overlapping with multi-periods. As part of the recommendation, during the planned equipment downtime, major repairs and maintenance were also to be carried out before critical field operations' period to improve pre-field and in-field efficiency for effective equipment and field operational planning and management.

\section{ACKNOWLEDGEMENT}

I hereby acknowledge The World Bank Sponsored Project of African Centre of Excellence in Agricultural Development and Sustainable Environment (CAEDESE), Federal University of Agriculture, Abeokuta, Nigeria for sponsoring this one month Faculty Outreach (2018) at Flour Mills Nigeria Plc, Sunti Golden Sugar Company, Niger State, Nigeria. Also acknowledged are the Sunti Golden Sugar Company Staff team who contributed immensely to the success of this study comprising Mr. Andries L. Du Pisani (General Manager), Engr. Samuel F. Okunola (Community Liaison Manager), Mr Arumaikarar C. Prabagar (Agronomist), Mr. Koenraad Strydom (Irrigation unit), Mr. Percy Mukwashi (Land development/preparation), Mr. Kotsev T. Lubomir (Technical/workshop services Manager), Mr. Rasheed A. Kuranga (GISAnalyst) and Alh. Ahmadu Adamu Lwafu (Community Liaison Officer).

\section{REFERENCES}

[1]. Hunt, D. 1979. Farm Power and Machinery Management. Iowa State University Press, Iowa, USA, $2^{\text {nd }}$ Edition, pp.267-269.

[2]. Deere, J. 1984. Machinery Management, Fundamentals of Machine Operation, Deere and Company Service Training. Illinois, USA.

[3].Yousif, L. A., Dahab, M. H. and EL-Ramlawi, H. R. 2013. Crop-Machinery Management System for Field Operations and Farm Machinery Selection. Journal of Agricultural Biotechnology and Sustainable Development. Academicjournals, 5(5), pp.84-90.

[4]. Edward, W. 2017. Farm Machinery Selection. Ag Decision Maker, Iowa State University Extension and Outreach, U.S.A. A3-28, pp.1-9.

[5]. Srivastava, A. K., Goering, C. E., Rohrbach, R. P. and Buckmaster, D. R. 2006. Engineering Principles of Agricultural Machines. $2^{\text {nd }}$ Edition, American Society of Agricultural and Biological Engineers, ASAE Publication 801M0206.

[6]. Coates, W. E. 2002. Agricultural Machinery Management. Published by College of Agriculture and Life Sciences, University of Arizona, USA. ACIS, pp.1-9. 
[7]. ASAE EP496.3 FEB2006. Agricultural Machinery Management. American Society of Agricultural and Biological Engineers, ASABE Standard.

[8]. ASAE EP496.2 DEC99. Agricultural Machinery Management. American Society of Agricultural and Biological Engineers, ASABE Standard.

[9]. ASAE D497.7 MAR2011. Agricultural Machinery Management Data. American Society of Agricultural and Biological Engineers, ASABE Standard.

[10]. Adisa, A. F. 2010. Operational Planning and Management of Mechanized Soybean/Maize Production Technology in Nigeria. Proceedings of the $19^{\text {th }}$ International Conference of Nigerian Institution of Agricultural Engineers, Enugu, Nigeria, pp. 110-117.

[11]. Kepner, R. A., Bainer, R., and Barger, E. L. 2005. Principles of Farm Machinery. $3^{\text {rd }}$ Edition, ISBN: 9788123909776.CBS Publishers \& Distributors, India, pp.1-515.

\title{
SISTEM UPRAVLJANJA USEVOM - MAŠINE ZA TERENSKE OPERACIJE I USVOJENE TEHNIKE PLANIRANJA ZA PROIZVODNJU ŠEĆERNE TRSKE
}

\author{
Alex Folami Adisa1, Nseobong Obioha Eberendu ${ }^{1}$ \\ \& \\ ${ }^{1}$ Agricultural and Bio-resources Engineering Department, \\ Federal University of Agriculture, P. M. B. 2240, Abeokuta, Nigeria
}

Apstrakt: Glavni ciljevi mehanizacije farme su maksimiziranje proizvodnje uz minimalne rizike i optimalnu cenu korišćenja mehanizacije i opreme dobrim planiranjem upravljanja i radom mašina za obavljanje pojedinih operacija proizvodnje useva za kompletan sistem . Zbog toga je ova studija bila potrebna kompaniji Sunti Golden Sugar u Nigeriji, da se u budućnosti utvrde na površini farme od 4.770 ha troškovi korišćenja opreme i odgovarajuća snaga traktora sa mašinama za gajenje i negu šećerne trske, kontrolu korova, žetvu trske i transport posle žetve do skladišta i postrojenja za preradu.. Na osnovu veličine/površine farme, faktora operativnog planiranja na terenu kao što su zemljišste, vremenske prilike/uslovi okoline, predviđena je svaka priključna mašina koja je usklađena sa odgovarajućom snagom traktora. Takođe su izračunati troškovi korišćenja za priključne mašine i traktor. Prikazan je kalendar svih tehnoloških operacija u polju sa šećernom trskom, koji je veoma važan za useve, a operativni redosled je preporučen $\mathrm{i}$ postavljen da se tehnološke operacije ne preklapaju u toku perioda gajenja useva.

Kao deo preporuke, tokom planiranih zastoja mašina, treba uraditi eventualne velike popravke i održavanje mašina pre perioda kritičnih tehnoloških operacija gajenja šećerne trske na terenu kako bi se pobolj̧šala efikasnost planiranja i upravljanja mašinama i opremom u radu.

Utvrdene se vrednosti: učinka svake mašine u okviru predvidenog raspoloživog vremena, stvarno potrebna snaga traktora, potrošnja goriva i ulja po jedinici vremena za uzgoj šećerne trske, žetvu i transport.

Takode su odabrane potrebne odgovarajuće mašine i oprema za sve dodatne radove sa zemljištem: na putevima, za navodnjavanje ili drenažu.

Ključne reči: Kalendar useva, mašine, upravljanje, rad, sekvenciranje 


\section{ZAHVALNOST}

Projekat African Centre of Excellence in Agricultural Development and Sustainable Environment (CAEDESE), Federal University of Agriculture, Abeokuta, Nigeria, je finansirala 2018. godine Svetska banka sa nazivom Flour Mills Nigeria Plc, Sunti Golden Sugar Company, Nigeria.

Autori izražavaju posebnu zahvalnost osoblju kompanije Sunti Golden Sugar, Nigerija, koje je mnogo doprinelo uspehu ove studije. Osoblje je u sastavu : Mr. Andries L. Du Pisani (General Manager), Engr. Samuel F. Okunola (Community Liaison Manager), Mr Arumaikarar C. Prabagar (Agronomist), Mr. Koenraad Strydom (Irrigation unit), Mr. Percy Mukwashi (Land development/preparation), Mr. Kotsev T. Lubomir (Technical/workshop services Manager), Mr. Rasheed A. Kuranga (GISAnalyst) and Alh. Ahmadu Adamu Lwafu (Community Liaison Officer).

Prijavljen:

Submitted: 28.05 .2021 .

Ispravljen:

Revised: $\quad 30.11 .2021$.

Prihvaćen:

Accepted: 13.12 .2021 